\title{
Upaya Meningkatkan Disiplin Guru dalam Kehadiran Mengajar Dikelas Melalui Penerapan Reward and Punishment di SMP Negeri 9 Kota Jambi
}

\author{
Nurhadi $^{1}$
}

\begin{abstract}
Abstrak: Peningkatan mutu pembelajaran disekolah sangat tergantung dari beberapa faktor. Faktor yang sangat penting antara lain adalah penerapan budaya sekolah kearah peningkatan mutu. Budaya sekolah merupakan hal yang positif yang harus dipertahankan dan dilaksanakan oleh semua warga sekolah tanpa merasa terpaksa. Budaya sekolah yang harus dipertahankan salah satunya adalah masalah kedisiplinan, termasuk disiplin para guru dalam kehadiran dikelas pada proses belajar mengajar. Untuk meningkatkan disiplin para guru dapat diupayakan melalui bermacammacam cara. Dalam Penelitian Tindakan Sekolah (PTS) ini, dicobakan tindakan berupa penerapan Reward and Punishment untuk para guru di SMP Negeri 9 kota Jambi.Penelitian ini dilaksanakan dalam dua siklus, karena dari hasil penelitian dan analisa data, ternyata pada siklus kedua, kedisiplinan guru dalam kehadiran dikelas pada proses belajar mengajar meningkat dan memenuhi indikator yang telah ditetapkan sebesar $75 \%$. Dari hasil penelitian ini, dapat disimpulkan bahwa untuk meningkatkan disiplin guru dalam kehadiran dikelas pada kegiatan belajar mengajar dapat dilakukan dengan penerapan Reward and Punishment kepada guru.
\end{abstract}

Kata Kunci: Disiplin Guru, Reward and Punishment

\begin{abstract}
Improving the quality of learning in schools depends on several factors. A very important factor is the application of school culture towards quality improvement. School culture is a positive thing that must be maintained and implemented by all school people without feeling forced. School culture that must be maintained is one of disciplinary problems, including the discipline of teachers in attendance in class in the teaching and learning process. To improve the discipline of teachers can be sought through various ways. In this School Action Research (SAR), the action was taken in the form of implementing Reward and Punishment for teachers in SMP Negeri 9 Kota Jambi. The study was conducted in two cycles, because of the results of research and data analysis, in the second cycle, teacher discipline in in the class in the teaching and learning process increases and fulfills the indicators that have been set at $75 \%$. From the results of this study, it can be concluded that increasing teacher discipline in class attendance in teaching and learning activities can be done by applying Reward and Punishment to teachers.
\end{abstract}

Keywords : Teacher Discipline, Reward and Punishment

\section{PENDAHULUAN}

Peningkatan mutu pendidikan sesuai dengan cita-cita bangsa Indonesia, yakni mewujudkan kesejahteraan umum dan mencerdaskan kehidupan bangsa, di mana pendidikan mempunyai peranan penting dalam meningkatkan ketakwaan kepada Tuhan Yang Maha Esa, kecerdasan, dan ketrampilan. Untuk itu maka perlu diadakan proses belajar mengajar, guru merupakan figur sentral, di tangan gurulah terletak kemungkinan berhasil atau tidaknya pencapaian tujuan belajar mengajar di sekolah. Oleh karena itu tugas dan peran guru bukan saja mendidik, mengajar dan melatih tetapi juga bagaimana guru dapat membaca situasi kelas dan kondisi siswanya dalam menerima pelajaran.

Dalam meningkatkan peranan guru dalam proses belajar mengajar dan hasil belajar siswa, maka guru diharapkan mampu menciptakan lingkungan belajar yang efektif dan akan mampu mengelola kelas. Guru adalah pendidik profesional dengan tugas utama mendidik dan mengevaluasi peserta didik, pada pendidikan anak usia dini jalur pendidikan formal, pendidikan dasar dan pendidikan menengah. Sementara pegawai dunia pendidikan merupakan bagian dari tenaga kependidikan, yaitu anggota masyarakat yang mengabdikan diri dan diangkat untuk menunjang penyelenggaraan pendidikan. Dalam informasi tentang wawasan Wiyatamandala, kedisiplinan guru diartikan sebagai sikap mental yang mengandung kerelaan mematuhi semua ketentuan, peraturan dan norma yang berlaku dalam menunaikan tugas dan tangung jawab.

Berdasarkan pengertian diatas dapat disimpulkan, kedisiplinan guru dan pegawai adalah sikap penuh kerelaan dalam mematuhi semua aturan dan norma yang ada dalam menjalankan tugasnya sebagai bentuk tanggung jawabnya terhadap pendidikan anak didiknya. Karena bagaimana pun seorang guru atau tenaga kependidikan (pegawai), merupakan cermin bagi anak didiknya dalam sikap atau teladan, dan sikap disiplin

\footnotetext{
${ }^{1}$ SMP Negeri 9 Kota Jambi, Indonesia
} 
guru dan tenaga kependidikan (pegawai) akan memberikan warna terhadap hasil pendidikan yang jauh lebih baik. Keberhasilan proses pembelajaran sangat bergantung pada beberapa faktor diantaranya adalah faktor guru. Guru sangat memegang peranan penting dalam keberhasilan proses pembelajaran. Guru yang mempunyai kompetensi yang baik tentunya akan sangat mendukung keberhasilan proses pembelajaran.

Peranan guru selain sebagai seorang pengajar, guru juga berperan sebagai seorang pendidik. Pendidik adalah seiap orang yang dengan sengaja mempengaruhi orang lain untuk mencapai tingkat kemanusiaan yang lebih tinggi (Sutari Imam Barnado, 1989:44). Sehinggga sebagai pendidik, seorang guru harus memiliki kesadaran atau merasa mempunyai tugas dan kewajiban untuk mendidik. Tugas mendidik adalah tugas yang amat mulia atas dasar "panggilan" yang teramat suci. Sebagai komponen sentral dalam sistem pendidikan, pendidik mempunyai peran utama dalam membangun fondamen-fondamen hari depan corak kemanusiaan. Corak kemanusiaan yang dibangun dalam rangka pembangunan nasional kita adalah "manusia Indonesia seutuhnya", yaitu manusia yang beriman dan bertaqwa kepada Tuhan Yang Maha Esa, percaya diri disiplin, bermoral dan bertanggung jawab. Untuk mewujudkan hal itu, keteladanan dari seorang guru sebagai pendidik sangat dibutuhkan.

Keteladanan guru dapat dilihat dari prilaku guru sehari-hari baik didalam sekolah maupun diluar sekolah. Selain keteladanan guru, kedisiplinan guru juga menjadi salah satu hal penting yang harus dimiliki oleh guru sebagai seorang pengajar dan pendidik. Fakta dilapangan yang sering kita jumpai disekolah adalah kurang disiplinnya guru, terutama masalah disiplin guru masuk kedalam kelas pada saat kegiatan pembelajaran dikelas.

Tujuan dari penelitian ini adalah ingin mencari alternatif pemecahan masalah sebagai upaya meningkatkan disiplin guru dalam kehadiran mengajar dikelas melalui penerapan Reward and Punishment. Kontribusi yang diharapkan dari penelitian ini antara lain: (1) Dapat menjadi wujud nyata kepala sekolah dalam memecahkan berbagai masalah disekolah melalui kegiatan penelitian; (2) Dapat menjadi motivasi guru dalam meningkatkan kedisiplinan dalam kehadiran; (3) Bentuk sumbangan dalam mewujudkan budaya sekolah yang dapat mendorong keberhasilan dan peningkatan mutu pembelajaran.

\section{Landasan Teori}

Di masa lalu, kepala sekolah yang berperan sebagai manajer yang efektif telah dianggap cukup. Di masa itu, kebanyakan kepala sekolah diharapkan mentaati ketentuan dan kebijakan Dinas Pendidikan, mengatasi isu-isu ketenagaan, pengadaan fasilitas dan infrastruktur, menyesuaikan anggaran, memelihara agar gedung sekolah nyaman dan aman, memelihara hubungan dengan masyarakat, memastikan kantin sekolah dan UKS berjalan lancar. Semua ini masih tetap harus dilakukan oleh kepala sekolah. Akan tetapi, sekarang kepala sekolah harus melakukan hal yang lebih dari semua itu.

Berbagai penelitian menunjukkan peran kunci yang dapat dilakukan kepala sekolah agar dapat meningkatkan belajar dan pembelajaran, jelas bahwa kepala sekolah harus berperan sebagai leaders for learning (The Institute for Educational Leadership, 2000). Para kepala sekolah harus mengetahui isi pelajaran dan teknik-teknik pedagogis. Para kepala sekolah juga harus bekerja bersama guru untuk meningkatkan keterampilan. Kepala sekolah harus mengumpulkan, menganalisis, dan menggunakan data dengan cara-cara yang menumbuhkan keunggulan. Mereka harus berkumpul bersama siswa, guru, orang tua, organisasi-organisasi layanan sosial dan kesehatan.

Selanjutnya kepala sekolah itu juga harus memiliki keterampilan dan pengetahuan kepemimpinan dalam rangka memanfaatkan kewenangannya untuk mencari strategi-strategi yang diperlukan. Mereka seharusnya melakukan itu semua, akan tetapi sering dijumpai bahwa mereka tidak melakukannya. Meskipun masyarakat pada umumnya memberi sorotan kepada kepala sekolah ketika hasil Ujian Nasional siswa diumumkan dan mengajukan usul untuk memberi sanksi apabila sekolah tidak menunjukkan hasil sebagaimana diharapkan, para kepala sekolah di masa lalu tidak banyak melalukan persiapan atau melakukan pengembangan keprofesionalan berkelanjutan untuk membekali diri dalam rangka melaksanakan peran baru tersebut. Pihak pemerintah daerah, atau dinas pendidikan, selama ini juga lebih banyak mendorong kepala sekolah untuk sekedar mentaati peraturan yang ada, kepala sekolah juga di tuntut untuk berusaha menjalankan tugasnya yang berlipat ganda, kebutuhan siswa yang kompleks, akuntabilitas yang terus meningkat, peningkatan keberagaman, dan sabagainya. Tidak ada alternatif lain, masyarakat di seluruh negeri ini harus "reinvent the principality" untuk memampukan para kepala sekolah dalam menghadapi 
tantangan abad 21 dan menjamin para pemimpin membimbing sekolah dan siswanya yang dipimpin agar mencapai keberhasilan. Pendidikan bukan hanya sekedar mengawetkan kebudayaan dan meneruskannya dari generasi ke generasi, akan tetapi juga diharapkan pendidikan dapat mengubah dan mengembangkan suatu pengetahuan. Pendidikan juga bukan hanya menyampaikan keterampilan yang sudah dikenal, namun harus dapat meramalkan berbagai jenis keterampilan dan kemahiran yang akan datang, dan sekaligus menemukan cara yang tepat dan cepat dikuasai oleh anak didik.(Budiningsih,2005).

Kemampuan dan keterampilan yang dimiliki seseorang tentu sesuai tingkat pendidikan yang diikutinya. Semakin tinggi pendidikan, maka di asumsikan semakin tinggi pula tingkat pengetahuan. Hal ini menggambarkan bahwa fungsi pendidikan dapat meningkatkan kesejahteraan, karena seseorang yang berpendidikan atau memiliki pendidikan tersebut dapat terhindar dari kebodohan dan juga kemiskinan.

Dapat ditegaskan fungsi pendidikan adalah membimbing anak didik ke arah suatu tujuan yang bernilai tinggi. Pendidikan yang baik adalah usaha yang berhasil membawa anak didik kepada tujuan itu (Sagala, 2003). Pada kegiatan belajar mengajar tenaga kependidikan (guru) merupakan suatu komponen yang penting dalam penyelenggaraan pendidikan. Guru sebagai tenaga pendidik adalah seseorang atau sekelompok orang yang berprofesi mengelola kegiatan belajar mengajar, serta seperangkat lainnya yang memungkinkan berlangsungnya kegiatan belajar mengajar lebih efektif. Berdasarkan atas tugas mengajarnya, maka seorang guru harus mempunyai wewenang mengajar berdasarkan kualifikasi sebagai tenaga pengajar. Kedudukan guru dipahami demikian penting sebagai ujung tombak dalam pembelajaran dan pencapaian mutu hasil belajar peserta didik (Sagala, 2003).

Keberhasilan siswa dalam pembelajaran serta peningkatan mutu sekolah tidak hanya menjadi tanggung jawab kepala sekolah saja, akan tetapi menjadi tanggung jawab bersama antara, guru, orang tua atau masyarakat serta pemerintah. Dalam bidang pendidikan, yang dimaksud dengan mutu memiliki pengertian sesuai dengan makna yang terkandung dalam siklus pembelajaran. Secara ringkas dapat disebutkan beberapa kata kunci pengertian mutu, yaitu: sesuai standar (fitness to standard), sesuai penggunaan pasar/pelanggan (fitness to use), sesuai perkembangan kebutuhan (fitness to latent requirements), dan sesuai lingkungan global (fitness to global environmental requirements). Adapun yang dimaksud mutu sesuai dengan standar, yaitu jika salah satu aspek dalam pengelolaan pendidikan itu sesuai dengan standar yang telah ditetapkan. Garvin seperti dikutip Gaspersz mendefinisikan delapan dimensi yang dapat digunakan untuk menganalisis karakteristik suatu mutu, yaitu: (1) kinerja (performance), (2) feature, (3) kehandalan (reliability), (4) konfirmasi (conformance), (5) durability, (6) kompetensi pelayanan (serviceability), (7) estetika (aestetics), dan (8) fit and finish;kualitas yang dipersepsikan pelanggan yang bersifat subjektif. Dalam pandangan masyarakat umum sering dijumpai bahwa mutu sekolah atau keunggulan sekolah dapat dilihat dari ukuran fisik sekolah, seperti gedung dan jumlah ekstra kurikuler yang disediakan. Ada pula masyarakat yang berpendapat bahwa kualitas sekolah dapat dilihat dari jumlah lulusan sekolah tersebut yang diterima di jenjang pendidikan selanjutnya. Untuk dapat memahami kualitas pendidikan formal di sekolah, perlu kiranya melihat pendidikan formal di sekolah sebagai suatu sistem. Selanjutnya mutu sistem tergantung pada mutu komponen yang membentuk sistem, serta proses yang berlangsung hingga membuahkan hasil.

Kinerja guru menjadi salah satu unsur dalam upaya peningkatan mutu sekolah. Kinerja guru meliputi kedisiplinan guru dan etos kerja. Apabila kedisiplinan telah menjadi budaya sekolah, maka arah pencapaian peningkatan mutu sekolah akan tercapai. Budaya sekolah adalah nilai-nilai dominan yang didukung oleh sekolah atau falsafah yang menuntun kebijakan sekolah terhadap semua unsur dan komponen sekolah termasuk stakeholders pendidikan, seperti cara melaksanakan pekerjaan di sekolah serta asumsi atau kepercayaan dasar yang dianut oleh personil sekolah.

Budaya sekolah merujuk pada suatu sistem nilai, kepercayaan dan norma-norma yang diterima secara bersama, serta dilaksanakan dengan penuh kesadaran sebagai perilaku alami, yang dibentuk oleh lingkungan yang menciptakan pemahaman yang sama diantara seluruh unsur dan personil sekolah baik itu kepala sekolah, guru, staf, siswa dan jika perlu membentuk opini masyarakat yang sama dengan sekolah. (Sudrajat, 2010).

Beberapa manfaat yang bisa diambil dari upaya pengembangan budaya sekolah, diantaranya : (1) menjamin kualitas kerja yang lebih baik; (2) membuka seluruh jaringan komunikasi dari segala jenis dan level baik komunikasi vertical maupun horisontal; (3) lebih terbuka dan transparan; (4) menciptakan 
kebersamaan dan rasa saling memiliki yang tinggi; (4) meningkatkan solidaritas dan rasa kekeluargaan; (5) jika menemukan kesalahan akan segera dapat diperbaiki; dan (6) dapat beradaptasi dengan baik terhadap perkembangan IPTEK. Selain beberapa manfaat di atas, manfaat lain bagi individu (pribadi) dan kelompok adalah : (1) meningkatkan kepuasan kerja; (2) pergaulan lebih akrab; (3) disiplin meningkat; (4) pengawasan fungsional bisa lebih ringan; (5) muncul keinginan untuk selalu ingin berbuat proaktif; (6) belajar dan berprestasi terus serta; dan (7) selalu ingin memberikan yang terbaik bagi sekolah, keluarga, orang lain dan diri sendiri.

Upaya pengembangan budaya sekolah seyogyanya mengacu kepada beberapa prinsip berikut ini.

1. Berfokus pada Visi, Misi dan Tujuan Sekolah. Pengembangan budaya sekolah harus senantiasa sejalan dengan visi, misi dan tujuan sekolah. Fungsi visi, misi, dan tujuan sekolah adalah mengarahkan pengembangan budaya sekolah. Visi tentang keunggulan mutu misalnya, harus disertai dengan program-program yang nyata mengenai penciptaan budaya sekolah.

2. Penciptaan Komunikasi Formal dan Informal. Komunikasi merupakan dasar bagi koordinasi dalam sekolah, termasuk dalam menyampaikan pesan-pesan pentingnya budaya sekolah. Komunikasi informal sama pentingnya dengan komunikasi formal. Dengan demikian kedua jalur komunikasi tersebut perlu digunakan dalam menyampaikan pesan secara efektif dan efisien.

3. Inovatif dan Bersedia Mengambil Resiko. Salah satu dimensi budaya organisasi adalah inovasi dan kesediaan mengambil resiko. Setiap perubahan budaya sekolah menyebabkan adanya resiko yang harus diterima khususnya bagi para pembaharu. Ketakutan akan resiko menyebabkan kurang beraninya seorang pemimpin mengambil sikap dan keputusan dalam waktu cepat.

4. Memiliki Strategi yang Jelas. Pengembangan budaya sekolah perlu ditopang oleh strategi dan program. Startegi mencakup cara-cara yang ditempuh sedangkan program menyangkut kegiatan operasional yang perlu dilakukan. Strategi dan program merupakan dua hal yang selalu berkaitan.

5. Berorientasi Kinerja. Pengembangan budaya sekolah perlu diarahkan pada sasaran yang sedapat mungkin dapat diukur. Sasaran yang dapat diukur akan mempermudah pengukuran capaian kinerja dari suatu sekolah.

6. Sistem Evaluasi yang Jelas. Untuk mengetahui kinerja pengembangan budaya sekolah perlu dilakukan evaluasi secara rutin dan bertahap: jangka pendek, sedang, dan jangka panjang. Karena itu perlu dikembangkan sistem evaluasi terutama dalam hal: kapan evaluasi dilakukan, siapa yang melakukan dan mekanisme tindak lanjut yang harus dilakukan.

7. Memiliki Komitmen yang Kuat. Komitmen dari pimpinan dan warga sekolah sangat menentukan implementasi program-program pengembangan budaya sekolah. Banyak bukti menunjukkan bahwa komitmen yang lemah terutama dari pimpinan menyebabkan program-program tidak terlaksana dengan baik.

8. Keputusan Berdasarkan Konsensus. Ciri budaya organisasi yang positif adalah pengembilan keputusan partisipatif yang berujung pada pengambilan keputusan secara konsensus. Meskipun hal itu tergantung pada situasi keputusan, namun pada umumnya konsensus dapat meningkatkan komitmen anggota organisasi dalam melaksanakan keputusan tersebut.

9. Sistem Imbalan yang Jelas. Pengembangan budaya sekolah hendaknya disertai dengan sistem imbalan meskipun tidak selalu dalam bentuk barang atau uang. Bentuk lainnya adalah penghargaan atau kredit poin terutama bagi siswa yang menunjukkan perilaku positif yang sejalan dengan pengembangan budaya sekolah.

10. Evaluasi Diri. Evaluasi diri merupakan salah satu alat untuk mengetahui masalah-masalah yang dihadapi di sekolah. Evaluasi dapat dilakukan dengan menggunakan pendekatan curah pendapat atau menggunakan skala penilaian diri. Kepala sekolah dapat mengembangkan metode penilaian diri yang berguna bagi pengembangan budaya sekolah. Halaman berikut ini dikemukakan satu contoh untuk mengukur budaya sekolah.

Selain mengacu kepada sejumlah prinsip di atas, upaya pengembangan budaya sekolah juga seyogyanya berpegang pada asas-asas berikut ini:

1. Kerjasama tim (team work). Pada dasarnya sebuah komunitas sekolah merupakan sebuah tim/kumpulan individu yang bekerja sama untuk mencapai tujuan. Untuk itu, nilai kerja sama merupakan 
suatu keharusan dan kerjasama merupakan aktivitas yang bertujuan untuk membangun kekuatankekuatan atau sumber daya yang dimilki oleh personil sekolah.

2. Kemampuan (ability). Menunjuk pada kemampuan untuk mengerjakan tugas dan tanggung jawab pada tingkat kelas atau sekolah. Dalam lingkungan pembelajaran, kemampuan profesional guru bukan hanya ditunjukkan dalam bidang akademik tetapi juga dalam bersikap dan bertindak yang mencerminkan pribadi pendidik.

3. Keinginan (willingness). Keinginan di sini merujuk pada kemauan atau kerelaan untuk melakukan tugas dan tanggung jawab untuk memberikan kepuasan terhadap siswa dan masyarakat. Semua nilai di atas tidak berarti apa-apa jika tidak diiringi dengan keinginan. Keinginan juga harus diarahkan pada usaha untuk memperbaiki dan meningkatkan kemampuan dan kompetensi diri dalam melaksanakan tugas dan tanggung jawab sebagai budaya yang muncul dalam diri pribadi baik sebagai kepala sekolah, guru, dan staf dalam memberikan pelayanan kepada siswa dan masyarakat.

4. Kegembiraan (happiness). Nilai kegembiraan ini harus dimiliki oleh seluruh personil sekolah dengan harapan kegembiraan yang kita miliki akan berimplikasi pada lingkungan dan iklim sekolah yang ramah dan menumbuhkan perasaan puas, nyaman, bahagia dan bangga sebagai bagian dari personil sekolah. Jika perlu dibuat wilayah-wilayah yang dapat membuat suasana dan memberi nuansa yang indah, nyaman, asri dan menyenangkan, seperti taman sekolah ditata dengan baik dan dibuat wilayah bebas masalah atau wilayah harus senyum dan sebagainya.

5. Hormat (respect). Rasa hormat merupakan nilai yang memperlihatkan penghargaan kepada siapa saja baik dalam lingkungan sekolah maupun dengan stakeholders pendidikan lainnya. Keluhan-keluhan yang terjadi karena perasaan tidak dihargai atau tidak diperlakukan dengan wajar akan menjadikan sekolah kurang dipercaya. Sikap respek dapat diungkapkan dengan cara member senyuman dan sapaan kepada siapa saja yang kita temui, bisa juga dengan memberikan hadiah yang menarik sebagai ungkapan rasa hormat dan penghargaan kita atas hasil kerja yang dilakukan dengan baik. Atau mengundang secara khusus dan menyampaikan selamat atas prestasi yang diperoleh dan sebagaianya.

6. Jujur (honesty). Nilai kejujuran merupakan nilai yang paling mendasar dalam lingkungan sekolah, baik kejujuran pada diri sendiri maupun kejujuran kepadaorang lain. Nilai kejujuran tidak terbatas pada kebenaran dalam melakukan pekerjaan atau tugas tetapi mencakup cara terbaik dalam membentuk pribadi yang obyektif. Tanpa kejujuran, kepercayaan tidak akan diperoleh. Oleh karena itu budaya jujur dalam setiap situasi dimanapun kita berada harus senantiasa dipertahankan. Jujur dalam memberikan penilaian, jujur dalam mengelola keuangan, jujur dalam penggunaan waktu serta konsisten pada tugas dan tanggung jawab merupakan pribadi yang kuat dalam menciptakan budaya sekolah yang baik.

7. Disiplin (discipline). Disiplin merupakan suatu bentuk ketaatan pada peraturan dan sanksi yang berlaku dalam lingkungan sekolah. Disiplin yang dimaksudkan dalam asas ini adalah sikap dan perilaku disiplin yang muncul karena kesadaran dan kerelaan kita untuk hidup teratur dan rapi serta mampu menempatkan sesuatu sesuai pada kondisi yang seharusnya. Jadi disiplin disini bukanlah sesuatu yang harus dan tidak harus dilakukan karena peraturan yang menuntut kita untuk taat pada aturan yang ada. Aturan atau tata tertib yang dipajang dimana-mana bahkan merupakan atribut, tidak akan menjamin untuk dipatuhi apabila tidak didukung dengan suasana atau iklim lingkungan sekolah yang disiplin. Disiplin tidak hanya berlaku pada orang tertentu saja di sekolah tetapi untuk semua personil sekolah tidak kecuali kepala sekolah, guru dan staf.

8. Empati (empathy). Empati adalah kemampuan menempatkan diri atau dapat merasakan apa yang dirasakan oleh orang lain namun tidak ikut larut dalam perasaan itu. Sikap ini perlu dimiliki oleh seluruh personil sekolah agar dalam berinteraksi dengan siapa saja dan dimana saja mereka dapat memahami penyebab dari masalah yang mungkin dihadapai oleh orang lain dan mampu menempatkan diri sesuai dengan harapan orang tersebut. Dengan sifat empati warga sekolah dapat menumbuhkan budaya sekolah yang lebih baik karena dilandasi oleh perasaan yang saling memahami.

9. Pengetahuan dan Kesopanan (knowledge and politeness). Pengetahuan dan kesopanan para personil sekolah yang disertai dengan kemampuan untuk memperoleh kepercayaan dari siapa saja akan memberikan kesan yang meyakinkan bagi orang lain. Dimensi ini menuntut para guru, staf dan kepala sekolah tarmpil, profesional dan terlatih dalam memainkan perannya memenuhi tuntutan dan kebutuhan siswa, orang tua dan masyarakat. Penerapan budaya sekolah termasuk penerapan disiplin semua warga 
sekolah dapat terwujud apabila semua warga sekolah mempunyai komitmen yang kuat untuk mewujudkannya.

Penerapan disiplin warga sekolah, khususnya disiplin guru dalam melaksanakan proses belajar mengajar sangat berkit kepada kinerja guru itu sendiri. Kinerja atau prestasi kerja guru dalam mengemban tugas keprofesionalan seperti mendidik, mengajar, membimbing, mengarahkan, melatih, menilai, dan mengevaluasi merupakan aspek utama dalam meningkatkan kecerdasan siswa yang membawa pada peningkatan mutu pendidikan yang diselenggarakan. Kinerja diartikan sebagai tingkat atau derajat pelaksanaan tugas seseorang atas dasar kompetensi yang dimilikinya. Istilah kinerja tidak dapat dipisahkan dengan bekerja karena kinerja merupakan hasil dari proses bekerja. Dalam konteks tersebut maka kinerja adalah hasil kerja dalam mencapai suatu tujuan atau persyaratan pekerjaan yang telah ditetapkan. Kinerja dapat dimaknai sebagai ekspresi potensi seseorang berupa perilaku atau cara seseorang dalam melaksanakan tugas, sehingga menghasilkan suatu produk (hasil kerja) yang merupakan wujud dari semua tugas serta tanggung jawab pekerjaan yang diberikan kepadanya.

Apabila disiplin guru telah dilaksanakan dengan baik dan kinerja guru juga baik, serta didukung oleh faktor-faktor lain yang mendukung maka akan tercipta kondisi sekolah yang kondusif yang pada akhirnya tujuan sekolah untuk menjadi sekolah yang bermutu akan dapat tercapai Disiplin adalah kesadaran dan kesediaan seseorang mentaati semua peraturan perusahaan dan norma-norma sosial yang berlaku. Adapun arti kesadaran adalah sikap seseorang yang secara sukarela menaati semua peraturan dan sadar akan tugas dan tanggung jawabnya. Sedangkan arti kesediaan adalah suatu sikap, tingkah laku, dan perbuatan seseorang yang sesuai dengan peraturan perusahaan baik yang tertulis maupun tidak (Hasibuan ,1997:212).

Menurut Davis disiplin kerja dapat diartikan sebagai pelaksanaan manajemen untuk memperteguh pedoman-pedoman organisasi (Mangkunegara, 2000 : 129). Disiplin pada hakikatnya adalah kemampuan untuk mengendalikan diri dalam bentuk tidak melakukan sesuatu tindakan yang tidak sesuai dan bertentangan dengan sesuatu yang telah ditetapkan dan melakukan sesuatu yang mendukung dan melindungi sesuatu yang telah ditetapkan. Dalam kehidupan sehari-hari dikenal dengan disiplin diri, disiplin belajar dan disiplin kerja. Disiplin kerja merupakan kemampuan seseorang untuk secara teratur, tekun secara terusmenerus dan bekerja sesuai dengan aturan-aturan yang berlaku dengan tidak melanggar aturan-aturan yang sudah ditetapkan. Pada dasarnya banyak indikator yang mempengaruhi tingkat kedisplinan karyawan suatu organisasi di antaranya ialah : (1) tujuan dan kemampuan, (2) teladan pimpinan, (3) balas jasa (gaji dan kesejahteraan), (4) keadilan, (5) waskat (pengawasan melekat), (6) sanksi hukuman, (7) ketegasan, dan (8) hubungan kemanusiaan (Hasibuan, 1997:213).

Disiplin juga merupakan salah satu fungsi manajemen sumber daya manusia yang penting dan merupakan kunci terwujudnya tujuan, karena tanpa adanya disiplin maka sulit mewujudkan tujuan yang maksimal (Sedarmayanti, 221:10).

Heidjrachman dan Husnan, (2002: 15) mengungkapkan "Disiplin adalah setiap perseorangan dan juga kelompok yang menjamin adanya kepatuhan terhadap perintah" dan berinisiatif untuk melakukan suatu tindakan yang diperlukan seandainya tidak ada perintah". Menurut Davis (2002: 112) "Disiplin adalah tindakan manajemen untuk memberikan semangat kepada pelaksanaan standar organisasi, ini adalah pelatihan yang mengarah pada upaya membenarkan dan melibatkan pengetahuan-pengetahuan sikap dan perilaku pegawai sehingga ada kemauan pada diri pegawai untuk menuju pada kerjasama dan prestasi yang lebih baik".

Disiplin itu sendiri diartikan sebagai kesediaan seseorang yang timbul dengan kesadaran sendiri untuk mengikuti peraturan-peratuan yang berlaku dalam organisasi. Dalam Peraturan Pemerintah Nomor 30 tahun 1980 tentang Peraturan Disiplin Pegawai Negeri Sipil telah diatur secara jelas bahwa kewajiban yang harus ditaati oleh setiap pegawai negeri sipil merupakan bentuk disiplin yang ditanamkan kepada setiap pegawai negeri sipil. Menurut Handoko (2001: 208) disiplin adalah kegiatan manajemen untuk menjalankan standar-standar organisasional. Ada dua tipe kegiatan pendisiplinan yaitu preventif dan korektif. Dalam pelaksanaan disiplin, untuk memperoleh hasil seperti yang diharapkan, maka pemimpin dalam usahanya perlu menggunakan pedoman tertentu sebagai landasan pelaksanaan.

Menurut Nitisemito (1986:199) menyatakan masalah kedisiplinan kerja, merupakan masalah yang perlu diperhatikan, sebab dengan adanya kedisiplinan, dapat mempengaruhi efektivitas dan efisiensi pencapaian tujuan organisasi. Sedangkan menurut Greenberg dan Baron (1993:104) memandang disiplin 
melalui adanya hukuman. Disiplin kerja, pada dasarnya dapat diartikan sebagai bentuk ketaatan dari perilaku seseorang dalam mematuhi ketentuan-ketentuan ataupun peraturan-peraturan tertentu yang berkaitan dengan pekerjaan, dan diberlakukan dalam suatu organisasi atau perusahaan (Subekti D., 1995). Dilihat dari sisi manajemen, terjadinya disiplin kerja itu akan melibatkan dua kegiatan pendisiplinan :

1. Preventif, pada pokoknya, dalam kegiatan ini bertujuan untuk mendorong disiplin diri di antara para karyawan, agar mengikuti berbagai standar atau aturan. Sehingga penyelewengan kerja dapat dicegah.

2. Korektif, kegiatan yang ditujukan untuk menangani pelanggaran terhadap aturan dan mencoba untuk menghindari pelanggaran-pelanggaran lebih lanjut (Heldjrachman dkk, 1990).

Perlu disadari bahwa untuk menciptakan disiplin kerja dalam organisasi/perusahaan dibutuhkan adanya :

a. Tata tertib/ peraturan yang jelas.

b. Penjabaran tugas dari wewenang yang cukup jelas.

c. Tata kerja yang sederhana, dan mudah diketahui oleh setiap anggota dalam organisasi.

Menurut Byars and Rue (1995:357) menyatakan ada beberapa hal yang dapat dipakai, sebagai indikasi tinggi rendahnya kedisplinan kerja karyawan, yaitu : Ketepatan waktu, kepatuhan terhadap atasan, peraturan terhadap perilaku terlarang, ketertiban terhadap peraturan yang berhubungan langsung dengan produktivitas kerja. Sedangkan De Cenzo dan Robbins (1994:451) mengemukakan tipe permasalahan dalam kedisiplinan, antara lain : kehadiran, perilaku dalam bekerja (dalam lingkungan kerja), ketidakjujuran, aktivitas di luar lingkungan kerja.

Melalui disiplin pula timbul keinginan dan kesadaran untuk menaati peraturan organisasi dan norma sosial. Namun tetap pengawasan terhadap pelaksanaan disiplin tersebut perlu dilakukan. Disiplin kerja adalah persepsi guru terhadap sikap pribadi guru dalam hal ketertiban dan keteraturan diri yang dimiliki oleh guru dalam bekerja di sekolah tanpa ada pelanggaran-pelanggaran yang merugikan dirinya, orang lain, atau lingkungannya. Dalam upaya penerapan kedisiplinan guru pada kehadiran dikelas dalam kegiatan belajar mengajar, bisa ditempuh dengan beberapa upaya. Adapun upaya dalam meningkatkan disiplin guru adalah sebagai berikut: (a) sekolah memiliki system pengendalian ketertiban yang dikelola dengan baik, (b) adanya keteladanan disiplin dalam sikap dan prilaku dimulai dari pimpinan sekolah, (c) mewajibkan guru untuk mengisi agenda kelas dan mengisi buku absen yang diedarkan oleh petugas piket, (d) pada awal masuk sekolah kepala sekolah bersama guru membuat kesepakatan tentang aturan kedisiplinan, (e) memperkecil kesempatan guru untuk ijin meninggalkan kelas, dan (f) setiap rapat pembinaan diumumkan frekuensi pelanggaran terendah. Dengan strategi tersebut diatas kultur disiplin guru dalam kegiatan pembelajaran bisa terpelihara dengan baik, suasana lingkungan belajar aman dan terkendali sehingga siswa bisa mencapai prestasi belajar yang optimal.

Sekolah yang menegakkan disiplin akan menjadi sekolah yang berkualitas, baik dari segi apapun juga, benarkah itu? Ini adalah bahasan sekilas dari satu sisi namun justru sangat primer (proses belajar-mengajar saja), tapi ini banyak terjadi di beberapa sekolah. Konon bagaimanapun atau apapun model dan kualitas inputnya semua akan menjadi berkualitas, semua bisa dilakukan lewat disiplin. Mungkin ada benarnya. Setidaknya membuat lingkungan sekolah berdisiplin, terutama disiplin dalam belajar dan proses mengajar. Setidaknya pengkondisian dalam soal disiplin akan membuat image tersendiri di lingkungan sekitar tentang kondisi sekolah.

Disiplin di sini diartikan ketaatan pada peraturan. Dari sini semuanya bermula, sebelum disiplin diterapkan perlu dibuat peraturan atau tata tertib yang benar-benar realistik menuju suatu titik, yaitu kualitas tadi. Lalu mengapa banyak sekolah yang mutunya rendah baik ditinjau dari nilai-nilai siswa, kinerja personal sekolah. Jawabanya mungkin disebabkan masih belum jelasnya peraturan sehingga tidak mudah diaplikasikan, atau buruknya pengawalan penerapan peraturan itu. Dalam hal ini kekurang konsistenan semua pihak. Bahkan kadang gurupun tidak tahu apa yang harus dilakukan dalam kelas, sehingga ia hanya mengajar apa adanya terkesan menghabiskan waktu mengajar saja. Banyak hal yang harus ditangani dalam ranah pendidikan di sekolah, tapi jika itu terlalu berat mungkin bisa saja sedikit dikurangi hanya untuk hal belajar dan mengajar saja. Selama ini yang terjadi di beberapa sekolah adalah seringnya kelas kosong saat jam belajar. Ini dikarenakan guru tidak hadir di kelas dan tanpa ada tugas yang harus dikerjakan siswa. Ketidak hadiran guru itu bisa saja karena kepentingan dinas atau yang lain. 
Ketidak tepatan dalam hal guru masuk kelas sehingga jeda waktu pergantian jam bisa dimanfaatkan siswa untuk melakukan tindakan indisipliner. Komitmen guru dalam hal ini kadang sering menjadi penyebabnya. Dalam manajemen sekolah, biasanya pengawasan banyak yang tidak bisa berjalan dengan baik, lebih-lebih jika komitmen guru dan siswa rendah maka sekolah-pun akhirnya sulit majunya.

Penerapan disiplin dapat ditegakan melalui pemberian reward and punishment. Reward dan punishment merupakan dua bentuk metode dalam memotivasi seseorang untuk melakukan kebaikan dan meningkatkan prestasinya. Kedua metode ini sudah cukup lama dikenal dalam dunia kerja. Tidak hanya dalam dunia kerja, dalam dunia penidikan pun kedua ini kerap kali digunakan. Namun selalu terjadi perbedaan pandangan, mana yang lebih diprioritaskan antara reward dengan punishment.

Reward artinya ganjaran, hadiah, penghargaan atau imbalan. Dalam konsep manajemen, reward merupakan salah satu alat untuk peningkatan motivasi para pegawai. Metode ini bisa meng-asosiasi-kan perbuatan dan kelakuan seseorang dengan perasaan bahagia, senang, dan biasanya akan membuat mereka melakukan suatu perbuatan yang baik secara berulang-ulang. Selain motivasi, reward juga bertujuan agar seseorang menjadi giat lagi usahanya untuk memperbaiki atau meningkatkan prestasi yang telah dapat dicapainya. Sementara punishment diartikan sebagai hukuman atau sanksi. Jika reward merupakan bentuk reinforcement yang positif, maka punishment sebagai bentuk reinforcement yang negatif, tetapi kalau diberikan secara tepat dan bijak bisa menjadi alat motivasi. Tujuan dari metode ini adalah menimbulkan rasa tidak senang pada seseorang supaya mereka jangan membuat sesuatu yang jahat. Jadi, hukuman yang dilakukan mesti bersifat pedagogies, yaitu untuk memperbaiki dan mendidik ke arah yang lebih baik.

Pada dasarnya keduanya sama-sama dibutuhkan dalam memotivasi seseorang, termasuk dalam memotivasi para pegawai dalam meningkatkan kinerjanya. Keduanya merupakan reaksi dari seorang pimpinan terhadap kinerja dan produktivitas yang telah ditunjukkan oleh bawahannya; hukuman untuk perbuatan jahat dan ganjaran untuk perbuatan baik. Melihat dari fungsinya itu, seolah keduanya berlawanan, tetapi pada hakekatnya sama-sama bertujuan agar seseorang menjadi lebih baik, termasuk dalam memotivasi para pegawai dalam bekerja.

Reward dan punishment dikenal sebagai ganjaran, merupakan dua metode yang lazim diterapkan di sebuah organisasi, instansi, atau perusahaan yang menargetkan adanya produktivitas kerja yang tinggi dari para karyawannya. Menurut Amaryllia, konsultan manajemen dan strategi dari Sien Consultan, dalam sejarahnya, reward dan punishment kali pertama banyak diterapkan di bidang penjualan (sales). Namun, kini metode tersebut banyak diadopsi oleh organisasi, perusahaan yang bergerak di pelbagi bidang, bahkan dunia pendidikan.

Penerapan reward dan punishment dalam dunia pendidikan dapat diterapkan sepanjang hal tersebut tidak bertentangan dengan tujuan pendidikan itu sendiri. Penerapan reward dan punishment juga tidak hanya diterapkan kepada siswa yang berprestasi atau yang melanggar tata-tertib, tetapi juga dapat diterapkan kepada guru-guru agar mereka berdisiplin dalam mengajar untuk memenuhi tugas mereka memberikan pelajaran kepada siswanya.

Reward dan punishment merupakan dua bentuk metode dalam memotivasi seseorang untuk melakukan kebaikan dan meningkatkan prestasinya. Kedua metode ini sudah cukup lama dikenal dalam dunia kerja. Tidak hanya dalam dunia kerja, dalam dunia penidikan pun kedua ini kerap kali digunakan. Namun selalu terjadi perbedaan pandangan, mana yang lebih diprioritaskan antara reward dengan punishment.

Dalam proses penataan birokrasi menjadi efektif lagi menyenangkan, hendaklah pemerintah dengan tegas memperhatikan dan menata sistem reward dan punishment. Hal ini harus diimplemntasikan sampai level bawah pemerintahan. Dengan begitu, diharapkan kualitas birokrasi meningkat, begitu pula kinerja aparat birorasi dalam dunia kerja semakin bermutu. Reward yang diberikan pun harus secara adil dan bijak. Jika tidak, reward malah menimbulkan rasa cemburu dan "persaingan yang tidak sehat" serta memicu rasa sombong bagi pegawai yang memperolehnya. Tidak pula membuat seseorang terlena dalam pujian dan hadiah yang diberikan sehingga membuatnya lupa diri. Oleh karena itu, prinsip keadilan sangat dibutuhkan dalam pemberian reward. Sebaliknya, jika punishment memang harus diberlakukan, maka laksanakanlah dengan cara yang bijak lagi mendidik, tidak boleh sewenang-wenang, tidak pula menimbulkan rasa kebencian yang berlebihan sehingga merusak tali silaturrahim. Dalam proses penataan birokrasi, hendaknya punishment yang diberikan kepada pegawai yang melanggar aturan telah disosialisasikan sebelumnya. Dan 
sebaiknya sanksi itu sama-sama disepakati, sehingga mendorong si terhukum untuk bisa mempertanggungjawabkan perbuatannya dengan ikhlas.

Selanjutnya hukuman yang diberikan bukanlah dengan kekerasan, tetapi diberikan dengan ketegasan. Jika hukuman dilakukan dengan kekerasan, maka hukuman tidak lagi memotivasi seseorang berbuat baik, melainkan membuatnya merasa takut dan benci sehingga bisa menimbulkan pemberontakan batin. Di sinilah dibutuhkan skill dari para pimpinan atau si pemberi punishment sehingga tujuan yang diinginkan dapat tercapai secara efektif. Dalam konteks pembelajaran dikelas yang berkaitan dengan kedisiplinan guru dalam melaksanakan tugas, penerapan metode reward dan punishment juga dapat meningkatkan motivasi guru untuk hadir tepat waktu pada kegiatan pembelajaran didalam kelas.

Bukanlah hal yang aneh kalau siswa sering mengeluh tentang ketidakhadiran guru dalam kegiatan belajar mengajar. Tidak pula asing kita dengan siswa mengeluh tentang adanya guru yang menyampaikan pelajaran kurang dari waktu yang telah ditentukan, atau menyampaikan materi seadanya. Yang ironis, ada pula guru yang menuliskan kehadirannya di kelas padahal sebenarnya ia tidak menyampaikan pelajaran kepada siswanya. Hal seperti ini tentu sangat mengecewakan siswa yang serius untuk mengikuti perkuliahan.

Bagi guru, ketidakhadiran dalam mengajar sesuai jadwal terkadang merupakan suatu hal yang tidak terhindarkan, mengingat suatu kali mereka mempunyai keperluan yang mendadak dalam waktu yang sama sehingga tidak mengajar. Namun hal demikian menjadi tidak wajar jika ketidak hadiran atau keterlambatan mengajar dikelas selalu dan sering terjadi. Hal ini berdampak buruk terhadap proses pembelajaran. Pertama, siswa menjadi kecewa, dan hal ini dapat menurunkan motivasi belajar mereka. Siswa memperoleh contoh yang buruk tentang kedisiplinan. Kedua, guru yang mengajar dengan sungguh-sungguh merasa usahanya menjadi sia-sia dan sekaligus kecewa. Apa yang mereka bangun dipatahkan oleh rekan seprofesinya. Belum lagi, apabila guru yang disiplin dalam mengajar, memperoleh pendapatan yang sama dengan guru yang jarang mengajar di kelas. Dampak dari guru yang malas untuk mengajar bukan semata ditanggung mereka namun juga seluruh institusi atau warga sekolah. Perilaku malas untuk mengajar juga bisa menjadi virus bagi guru yang biasanya rajin mengajar.

Peran reward dan punishment bagi SDM inipun juga harus dibawa menjadi bentuk participative. Likert (1967) menyebutkan dalam salah satu sistem manajemen participative ini mengakui dan berusaha memenuhi kebutuhan-kebutuhan manusiawi para pekerja. Tidak saja kebutuhan faali, tetapi juga kebutuhankebutuhan lainnya.

Motivasi kerja tidak saja ditimbulkan melalui hadiah-hadiah ekonomis, tetapi juga melalui partisipasi dalam kelompok dan keterlibatannya dalam menentukan tujuantujuan pekerjaannya. Sikap kooperatif dan tenggang rasa (favorable) terhadap para tenaga kerja lainnya dalam organisasi. Bentuk partisipasi pengambilan keputusan dilakukan meluas dalam organisasi. Namun terintegrasi dengan baik. Dalam system manajemen ini dapat dikatakan tidak dirasakan adanya hubungan ketergantungan yang tidak seimbang dari bawahan terhadap atasan.

Penerapan lain juga bisa diterapkan bagi karyawan atau aparatur meningkatkan disiplin SDM aparatur yang masih rendah dengan perubahan perilaku yang mendasar. Hal itu terjadi melalui revitalisasi pembinaan kepegawaian dan proses pembelajaran dengan membangun komitmen kuat dalam mengemban tugas sebagai pegawai negeri sipil, disertai pengembangan sistem reward dan punishment yang tepat dan efektif (Nugroho, 2006).

Pemberian rewards and punishments sangat berkaitan dengan terlaksananya kedisiplinan guru dalam kegiatan belajar mengajar dikelas. Kepala sekolah selaku pemimpin pembelajaran mempunyai peran yang sangat strategis dalam pencapaian tujuan sekolah dalam meningkatkan mutu. Salah satu faktor yang penting adalah adanya keteladanan (contoh) dalam kedisiplinan yang diberikan oleh kepala sekolah. Hal ini seperti falsafah pendidikan yang dikemukakan oleh Bapak Pendidikan Nasional Ki Hadjar Dewantara, "Ing Ngarso Sung Tuladha."'Kepala sekolah selaku pemimpin pembelajaran harus bisa memberikan contoh kepada semua wara sekolah agar tercipta budaya disiplin disekolah, yang pada akhirnya akan meningkatkan mutu sekolah. 
Penelitian ini adalah Penelitian Tindakan Sekolah (PTS) dengan pendekatan kualitatif. PTS merupakan suatu prosedur penelitian yang diadaptasi dari Penelitian Tindakan Kelas (PTK). Secara singkat, PTS bertujuan untuk mencari pemecahan permasalahan nyata yang terjadi di sekolah-sekolah, sekaligus mencari jawaban ilmiah bagaimana masalah-masalah tersebut bisa dipecahkan melalui suatu tindakan perbaikan.

Penelitian ini mengacu pada penelitian tindakan model Stephen Kemmis dan Mc. Taggart (1998) yang diadopsi oleh Suranto $(2000 ; 49)$. Model penelitian ini menggunakan sistem spiral refleksi diri yang dimulai dari rencana, tindakan, pengamatan, refleksi, dan perencanaan kembali yang merupakan dasar untuk suatu ancang-ancang pemecahan masalah. Langkah-langkah penelitian tindakan sekolah dapat digambarkan seperti flowchart dibawah ini :

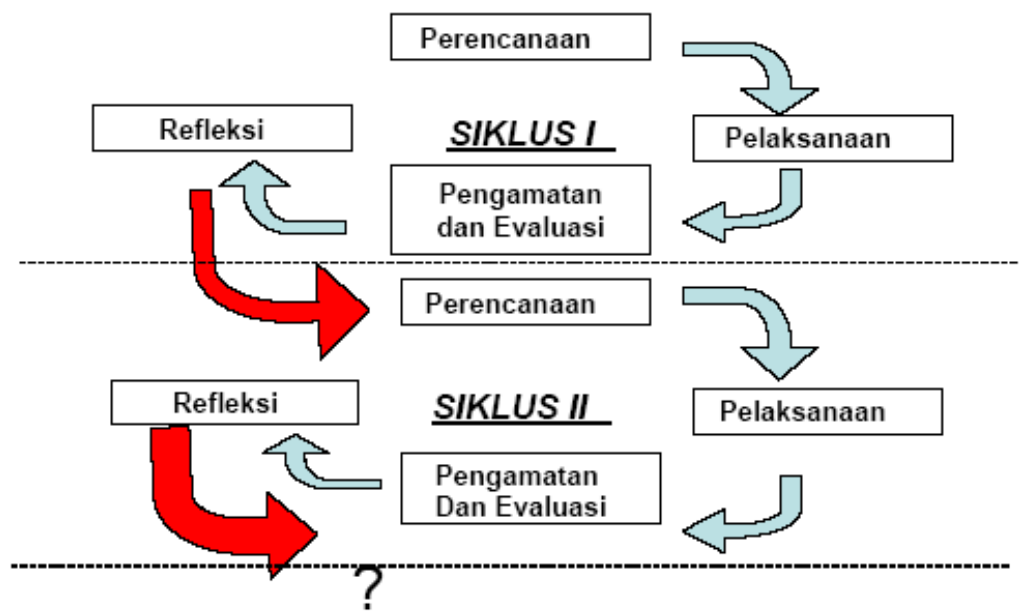

\section{Lokasi dan Waktu Penelitian}

Penelitian ini dilakukan di SMP Negeri 9 Kota Jambi. Waktu penelitian dimulai sejak 1 Februari s/d 7 Mei 2017. Subjek penelitian ini adalah guru-guru di SMP Negeri 9 Kota Jambi, sejumlah 42 orang guru PNS dan Non PNS, terdiri atas 32 orang guru PNS, dan 10 orang guru non PNS.

\section{Tindakan}

Tindakan yang dilakukan dalam penelitian ini adalah pemberian reward dan punishment kepada guru mengenai kedisiplinan guru dalam kehadiran dikelas dalam proses pembelajaran oleh kepala sekolah. Diharapkan dengan pemberian reward dan punishment yang diberikan oleh kepala sekolah akan terjadi perubahan atau peningkatan kedisiplinan guru dalam kehadiran dikelas dalam proses pembelajaran. Karena keterbatasan waktu, penelitian tindakan sekolah ini hanya dilaksanakan sebanyak dua siklus. Masing-masing siklus dilaksanakan selama satu minggu.

\section{Teknik Pengumpulan Data}

Teknik pengumpulan data dari penelitian tindakan sekolah ini adalah melalui data kualitatif yang diperoleh dari observasi, pengamatan, maupun wawancara.

1. Wawancara.

Teknik ini digunakan untuk mendapatkan data dari informan secara langsung. Dalam melakukan wawancara dipergunakan pedoman wawancara yang terbuka.

2. Pengumpulan data sekunder

Teknik ini digunakan untuk mengumpul data sekunder melalui dokumen-dokumen tertulis yang diyakini integritasnya karena mengambil dari berbagai sumber yang relevan dengan penelitian. Pengambilan sumber yang bersifat sekunder ini dapat diperoleh dari hasil dialog bersama kolaborator, data base sekolah, dan lain-lain.

3. Observasi atau pengamatan

Observasi digunakan untuk melengkapi data dari wawancara dan pengumpulan dokumentasi, terutama dalam lingkup masalah penelitian, antara lain mengamati impelementasi kebijakan yang berkaitan dengan kedisiplinan guru dalam kehadiran dikelas pada kegiatan belajar mengajar. 


\section{Instrumen Penelitian}

Instrumen penelitian yang digunakan dalam penelitian tindakan sekolah ini antara lain adalah :

1. Skala Penilaian

2. Lembar Pengamatan

3. Angket

\section{Teknik Analisis Data}

Analisa data yang digunakan dalam penelitian ini adalah analisa data kualitatif yang bersumber dari data primer maupun empiris. Melalui analisa data ini, dapat diketahui ada tidaknya peningkatan kedisiplinan guru dalam kehadiran dikelas melalui pemberian reward dan punishment yang merupakan fokus dari penelitian tindakan sekolah ini.

\section{HASIL DAN PEMBAHASAN Siklus 1}

Siklus 1 terdiri atas beberapa tahap, yaitu : (1) Perencanaan, (2) Pelaksanaan, (3) Pengamatan dan Evaluasi, dan (4) Refleksi.

\section{Perencanaan}

Perencanaan adalah langkah awal yang dilakukan oleh penulis saat akan memulai tindakan. Agar perencanaan mudah dipahami dan dilaksanakan oleh penulis yang akan melakukan tindakan, maka penulis membuat rencana tindakan sebagai berikut :

a. Merumusan masalah yang akan dicari solusinya. Dalam penelitian ini masalah yang akan dicari solusinya adalah masih banyaknya guru yang kurang disiplin dalam kehadiran dikelas pada proses belajar mengajar.

b. Merumuskan tujuan penyelesaian masalah/tujuan menghadapi tantangan/tujuan melakukan inovasi/tindakan. Dalam penelitian ini penulis mengambil rencana untuk melakukan tindakan memberikan Reward dan Punishment kepada guruguru untuk meningkatkan kedisiplinan guru dalam kehadiran dikelas pada proses belajar mengajar.

c. Merumusan indikator keberhasilan penerapan Reward dan Punishment dalam meningkatkan disiplin guru dalam kehadiran dikelas pada proses belajar mengajar. Indikator keberhasilan penerapan tindakan ini penulis tetapkan sebesar $75 \%$, artinya tindakan ini dinyatakan berhasil bila $75 \%$ guru tidak terlambat masuk kelas dalam proses pembelajaran.

d. Merumusan langkah-langkah kegiatan penyelesaian masalah/kegiatan menghadapi tantangan/kegiatan melakukan tindakan. Langkah-langkah yang diambil penulis dalam melakukan tindakan antara lain adalah melakukan sosialisasi kepada para guru mengenai penelitian yang akan dilaksanakan, serta menyampaikan tujuan dari penerapan tindakan yang dilakukan oleh penulis. Kepada para guru disampaikan mengenai penerapan Reward dan Punishment yang akan diterapkan dalam penelitian ini. Pada siklus pertama ini, akan dipampang/ditempel diruang guru, maupun diruang TU, peringkat namanama guru yang paling rendah tingkat keterlambatan masuk kelasnya sampai yang paling tinggi tingkat keterlambatannya.

e. Mengidentifikasi warga sekolah dan atau pihak-pihak terkait lainnya yang terlibat dalam penyelesaian masalah/menghadapi tantangan/melakukan tindakan. Penulis melakukan identifikasi siapa saja yang dilibatkan dalam penelitian ini. Pihak-pihak yang dilibatkan dalam penelitian ini adalah : guru, guru piket, TU, dan siswa.

f. Mengidentifikasi metode pengumpulan data yang akan digunakan. Metode pengumpulan data yang diambil oleh penulis merupakan data kualitatif melalui observasi, pengamatan serta wawancara kepada siswa mengenai kehadiran guru dikelas pada kegiatan belajar mengajar.

g. Penyusunan instrumen pengamatan dan evaluasi. Dalam pengambilan data, penulis menggunakan instrument berupa lembar observasi/pengamatan, skala penilaian serta angket yang disebarkan kepada siswa, untuk mengetahui penilaian dari siswa mengenai tingkat kehadiran guru dikelas dalam proses kegiatan belajar mengajar. 
h. Mengidenifikasi fasilitas yang diperlukan. Fasilitas atau alat bantu yang digunakan dalam penelitian ini antara lain : kertas (lembar pengamatan), alat tulis berupa balpoin, serta jam dinding yang ada disetiap kelas, serta rekap jumlah kehadiran dari setiap guru.

\section{Pelaksanaan}

Pelaksanaan penelitian tindakan sekolah ini dilaksanakan melalui beberapa kegiatan, antara lain :

a. Menyebarkan lembar pengamatan kepada setiap Ketua Kelas atau Sekretaris kelas, sesuai dengan banyaknya jumlah rombongan belajar di SMP Negeri 9 Kota Jambi, sebanyak 23 rombongan belajar. Dalam lembar pengamatan itu, telah dibuat daftar guru yang mengajar dikelas itu setiap jam dan diberi kolom jam masuk kelas serta jam keluar kelas. Lembar pengamatan dapat dilihat pada lampiran.

b. Berkoordinasi dengan petugas piket yang setiap hari terdiri dari 3 orang petugas, yaitu dari guru yang tidak mempunyai jam mengajar pada hari itu. Petugas piket akan mengedarkan daftar hadir guru dikelas yang telah dibuat agar dapat melihat tingkat kehadiran guru disetiap kelas dan disetiap pergantian jam pelajaran. Guru yang terlambat lebih dari 15 menit, dianggap tidak hadir dan diberi tanda silang. Daftar hadir guru dapat dilihat dalam lampiran.

c. Setelah selesai jam pelajaran, dilakukan rekapitulasi dari hasil pengamatan, baik dari guru piket, dari siswa maupun dari penulis.

d. Kegiatan tersebut dilakukan terus setiap hari kepada setiap guru selama satu minggu (satu siklus).

\section{Pengamatan dan Evaluasi}

Pengamatan atau observasi dilakukan oleh peneliti dengan menggunakan lembar observasi selama satu minggu (satu siklus), untuk semua guru yang berjumlah 42 orang. Selama pengamatan peneliti dibantu atau berkolaborasi dengan guru piket. Pengamatan oleh peneliti meliputi :

a. Kehadiran guru dikelas

b. Tingkat keterlambatan guru masuk kelas

c. Waktu meninggalkan kelas setelah selesai pelajaran

Peneliti juga melakukan penilaian dari hasil lembar observasi yang dibagikan kepada pengurus kelas untuk mengamati kehadiran guru dikelas. Dari hasil pengamatan serta rekap dari tingkat kehadiran guru dikelas pada proses belajar mengajar dapat dilihat pada tabel berikut :

Tabel 1.

Rekapitulasi Tingkat Keterlambatan Guru Pada Kehadiran Dikelas Siklus I

Waktu Keterlambatan/Jumlah/Prosentase

\begin{tabular}{ccc} 
Kurang dari 10 Menit & 10 Menit s.d 15 Menit & Lebih dari 15 Menit \\
\hline 11 orang & 14 orang & 17 orang \\
$26,19 \%$ & $33,33 \%$ & $40,47 \%$ \\
\hline
\end{tabular}

Dari hasil rekapitulasi tingkat keterlambatan guru dikelas pada proses pembelajaran diperoleh data, sebanyak 5 orang guru terlambat masuk kelas kurang dari 10 menit, 7 orang guru terlambat masuk kelas 10 menit sampai dengan 15 menit, dan 9 orang guru terlambat masuk kelas lebih dari 15 menit. Untuk lebih jelasnya dapat digambarkan pada grafik dibawah ini:

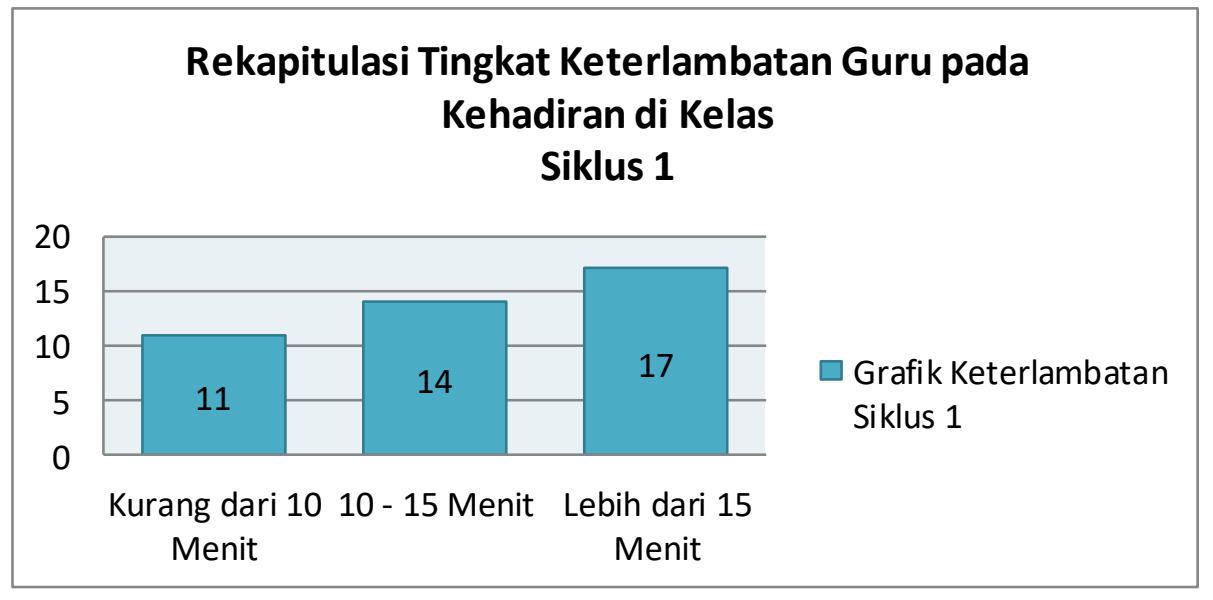


Dari data diatas dapat ditarik kesimpulan bahwa tingkat keterlambatan guru masuk kelas lebih dari 15 menit pada proses kegiatan belajar mengajar masih tinggi yaitu 9 orang atau 47,83\%. Berdasarkan indicator yang telah ditetapkan bahwa keberhasilan tindakan ini adalah $75 \%$, atau bila $75 \%$ guru tidak terlambat lebih dari 10 menit. Pada siklus pertama ini guru yang tidak terlambat lebih dari 10 menit baru $21,74 \%$, jadi peneliti berkesimpulan harus diadakan penelitian atau tindakan lagi pada siklus berikutnya atau siklus kedua.

Refleksi

Setelah selesai satu siklus maka diadakan refleksi mengenai kelemahan atau kekurangan dari pelaksanaan tindakan pada siklus pertama. Refleksi dilaksanakan bersama-sama kolaborator untuk menentukan tindakan perbaikan pada siklus berikutnya.

Dari hasil refleksi dapat diambil suatu kesimpulan bahwa perlu penerapan Reward dan Punishment yang lebih tegas lagi daripada siklus pertama.

\section{Siklus II}

\section{Perencanaan}

Siklus II terdiri atas beberapa tahap, sama seperti siklus 1 yaitu :

Dari hasil refleksi pada siklus pertama, peneliti merencanakan untuk melakukan tindakan Reward dan Punishment yang lebih tegas dibandingkan dengan siklus pertama. Peneliti merencanakan untuk mengumumkan hasil observasi mengenai tingkat keterlambatan guru masuk kelas dalam proses belajar mengajar, pada kegiatan upacara bendera hari Senin. Hal ini terlebih dahulu disosialisasikan kepada semua guru pada saat refleksi siklus pertama.

\section{Pelaksanaan}

Pelaksanaan penelitian tindakan sekolah pada siklus yang kedua ini dilaksanakan melalui beberapa kegiatan, antara lain:

a. Menyebarkan lembar pengamatan kepada setiap Ketua Kelas atau Sekretaris kelas, sesuai dengan banyaknya jumlah rombongan belajar di SMP Negeri 9 Kota Jambi sebanyak 23 rombongan belajar. Dalam lembar pengamatan itu, telah dibuat daftar guru yang mengajar dikelas itu setiap jam dan diberi kolom jam masuk kelas serta jam keluar kelas. Lembar pengamatan dapat dilihat pada lampiran.

b. Berkoordinasi dengan petugas piket yang setiap hari terdiri dari 3 orang petugas, yaitu dari guru yang tidak mempunyai jam mengajar pada hari itu dan satu orang dari tata usaha. Petugas piket akan mengedarkan daftar hadir guru dikelas yang telah dibuat agar dapat melihat tingkat kehadiran guru disetiap kelas dan disetiap pergantian jam pelajaran. Guru yang terlambat lebih dari 15 menit, dianggap tidak hadir dan diberi tanda silang. Daftar hadir guru dapat dilihat dalam lampiran.

c. Setelah selesai jam pelajaran, dilakukan rekapitulasi dari hasil pengamatan, baik dari guru piket, dari siswa maupun dari penulis. Kegiatan tersebut dilakukan terus setiap hari kepada setiap guru selama satu minggu (satu siklus) pada siklus kedua

\section{Pengamatan dan Evaluasi}

Pengamatan atau observasi dilakukan oleh peneliti dengan menggunakan lembar observasi selama satu minggu (satu siklus), untuk semua guru yang berjumlah 42 orang. Selama pengamatan peneliti dibantu atau berkolaborasi dengan guru piket. Pengamatan oleh peneliti meliputi:

a. Kehadiran guru dikelas

b. Tingkat keterlambatan guru masuk kelas

c. Waktu meninggalkan kelas setelah selesai pelajaran

Peneliti juga melakukan penilaian dari hasil lembar observasi yang dibagikan kepada pengurus kelas untuk mengamati kehadiran guru dikelas. Dari hasil pengamatan serta rekap dari tingkat kehadiran guru dikelas pada proses belajar mengajar pada siklus kedua dapat dilihat pada tabel berikut:

Tabel 2.

Rekapitulasi Tingkat Keterlambatan Guru Pada Kehadiran Dikelas Siklus II

Waktu Keterlambatan/Jumlah/Prosentase

Kurang dari 10 Menit

10 Menit s.d 15 Menit

32 orang 10 orang

$76,19 \%$

Lebih dari 15 Menit

0 orang

$0 \%$ 
Dari hasil rekapitulasi tingkat keterlambatan guru dikelas pada proses pembelajaran diperoleh data, sebanyak 16 orang guru terlambat masuk kelas kurang dari 10 menit, 3 orang guru terlambat masuk kelas 10 menit sampai dengan 15 menit, dan tidak ada satu orangpun guru yang terlambat masuk kelas lebih dari 15 menit. Untuk lebih jelasnya, tingkat keterlambatan guru masuk kelas pada proses belajar mengajar pada siklus kedua ini dapat digambarkan pada grafik dibawah ini:

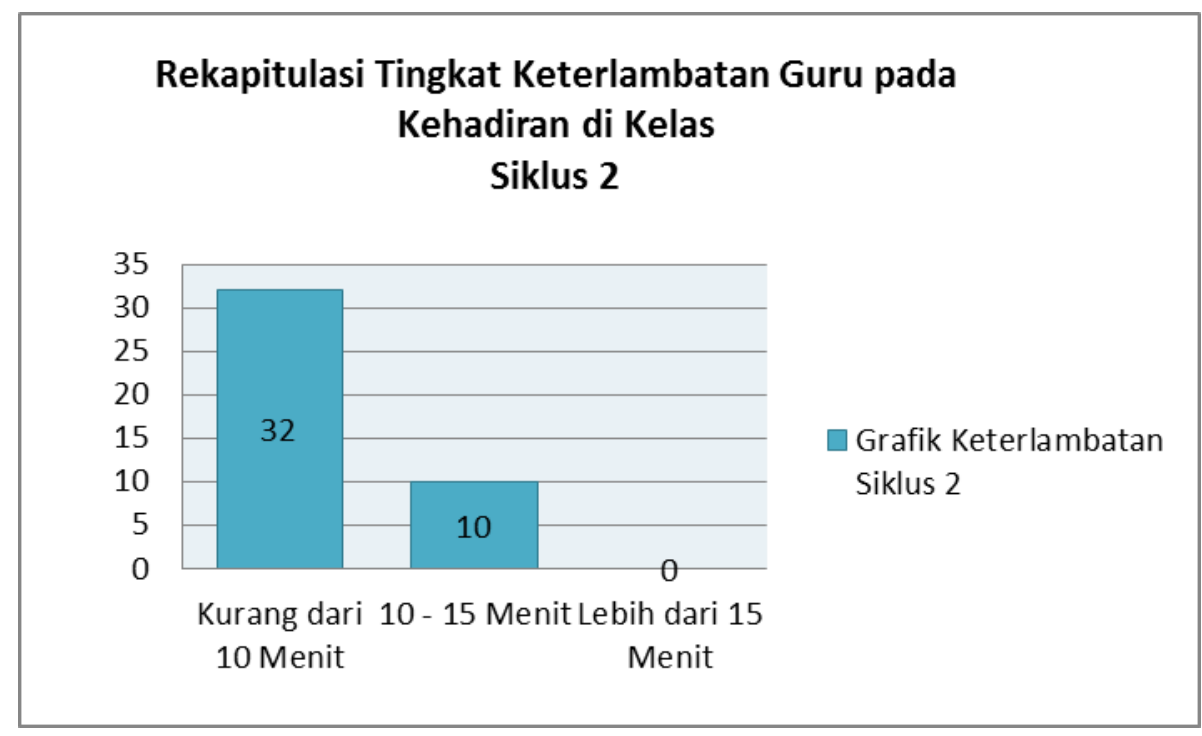

Dari hasil observasi pada siklus pertama dan siklus kedua dapat dilihat ada penurunan tingkat keterlambatan guru dikelas pada kegiatan belajar mengajar, atau terdapat peningkatan kehadiran guru dikelas.

\section{Refleksi}

Setelah selesai pelaksanaan tindakan pada siklus kedua maka diadakan refleksi mengenai kelemahan atau kekurangan dari pelaksanaan tindakan pada siklus kedua tersebut. Dari hasil observasi dan data yang diperoleh, peneliti mengambil kesimpulan bahwa tindakan yang dilaksanakan pada siklus kedua dinyatakan berhasil, karena terdapat $78,26 \%$ guru yang terlambat kurang dari 10 menit, atau melebihi target yang telah ditentukan sebesar $75 \%$.

\section{SIMPULAN}

Berdasarkan analisis data, dari penelitian ini dapat ditarik kesimpulan bahwa penerapan Reward dan Punishment efektif untuk meningkatkan disiplin kehadiran guru dikelas pada kegiatan belajar mengajar. Data yang diperoleh menunjukan bahwa setelah diadakan penerapan tindakan berupa Reward dan Punishment, guru yang terlambat lebih dari 15 menit adalah 0, dan guru yang terlambat kurang dari 10 menit sebanyak 16 orang guru. Penerapan Reward dan Punishment dapat meningkat disiplin guru hadir didalam kelas pada kegiatan belajar mengajar di SMP Negeri 9 Kota Jambi.

\section{DAFTAR PUSTAKA}

Amstrong. Michael, 1991. Manajemen Sumber Daya Manusia. Jakrta: Ghalia Indonesia Arikunto, S. 2002. Prosedur Penelitian Suatu Pendekatan Praktek. Jakarta: Rineka Cipta Aunurrahman. 2009. Belajar dan Pembelajaran. Bandung: Alfabeta

Departemen Pendidikan Nasional. (2003). Undang-undang Nomor 20 Tahun 2003 Tentang Sistem Pendidikan Nasional. Jakarta: Depdiknas

Hidayat, Sucherli. (1986). Peningkatan Produktivitas Organisasi dan Pegawai Negeri Sipil: Kasus Indonesia, Jakarta: Prisma

Mangkunegara, A. P. 1994. Psikologi Perusahaan. Bandung: PT. Trigenda Karya

Penerbit Remaja Rosdakarya. (2000). Manajemen Sumber Daya Manusia Perusahaan. Bandung: 
Megawangi, Ratna. (2007). Membangun SDM Indonesia Melalui Pendidikan Holistik Berbasis Karakter. Jakarta: Indonesian Heritage Foundation

Nugroho, B. (2006). Reward dan Punishment. Bulletin CiptaKarya Departemen Pekerjaan Umum Edisi No. 6/IV/Juni 2006

Sanjaya, W. (2008). Kurikulum dan Pembelajaran. Teori dan Praktik Pengembangan Kurikulum Tingkat Satuan Pendidikan (KTSP). Jakarta: Kencana Prenada Media Group

Subagio. (2010) Kompetensi Guru dalam Meningkatkan Mutu Pembelajaran [On Line]. Tersedia: http://subagio-subagio.blogspot.com/2010/03/kompetensi-guru dalammeningkatkanmutu.html

Sudrajat, A. 2010. Manfaat Prinsip dan Asas Pengembangan Budaya Sekolah. [On Line]. Tersedia: http://akhmadsudrajat.wordpress.com/2010/03/04/manfaatprinsip-dan-asas-pengembangan-budayasekolah/ [06 Oktober 2010] 